\title{
The Identification of Implementation of Central Learning Models
}

\author{
Hendra Sofyan \\ Teacher Education for Early Childhood Education \\ Jambi University, Indonesia \\ hendrapaud@yahoo.co.id
}

\author{
Nyimas Muazzomi \\ Teacher Education for Early Childhood Education \\ Jambi University, Indonesia \\ muazzominyimas@yahoo.com
}

\author{
Novi Lestari \\ Student Education Teacher Early Childhood Education \\ Jambi University, Indonesia
}

\begin{abstract}
This study aims to describe the implementation of the learning center model in Kindergarten, Sungai Gelam District, Muaro Jambi District. This type of research is descriptive through quantitative and qualitative approaches. Based on the results of research on the implementation of the learning center model in Kindergarten, Sungai Gelam District, Muaro Jambi Regency is of "Good" quality. From the results of an average questionnaire weight of $78 \%$ and an average result of an observation weight of $76 \%$ and strengthened the results of the interview where most of the teachers have implemented the center learning model in accordance with the stages. Based on the indicators, the identification of the implementation of the learning center model is at the "Good" quality with a questionnaire result of $76 \%$ and the observation result of $76 \%$ as well as the results of the interview proving that most of the teachers have carried out the preparation stages according to the procedure, in terms of the learning process being at the "Good" quality with a questionnaire result of $80 \%$ and an observation result of $76 \%$ as well as an interview which also proves that the majority of the teachers have carried out the learning process and at the evaluation stage are of "Good" quality with a questionnaire result of $76 \%$ and an observation result of $74 \%$ as well strengthened by the results of interviews that prove that most of the teachers have carried out the evaluation process in accordance with the procedure.
\end{abstract}

Keywords: identification, learning center model

\section{INTRODUCTION}

The success of coaching today is a success for children in the future. Conversely failure in handling early childhood is a disaster for the lives of children in the future. This is consistent with the opinion of Bloom in Susanto (2014) that the IQ of children will greatly develop in childhood with $20 \%$ at 1 year of age, $50 \%$ at 4 years of age, $80 \%$ at 8 years of age and $100 \%$ at a later age. This proves that education in early childhood is very important to do as well as possible, so that children can grow and develop according to the stages of their development optimally.

There are many new theories that support the importance of education in early childhood and one theory that reinforces the importance of education carried out from an early age is about the theory of Multiple Intelligence which reminds us that each child will have various intelligence potentials, the intelligence potential will develop optimally when it is developed early on through educational services that are appropriate to the level of child development, from the start of good facilities and infrastructure, the quality of professional teachers and the implementation of appropriate learning.

The rapid development of the era is very demanding changes from all fields, especially in terms of education. The 2013 curriculum that there are 4 learning models in early childhood: (1) group learning models based on activity angles; (2) group learning models but based on safety activities; (3) learning models based on areas and finally; and (4) learning models based on centers. The learning model based on this center has been widely used in various provinces in Indonesia. Learning models based on centers are done through educational games, and their use in grades can make a very good contribution to children's learning success when compared with other learning models.

In contrast to past learning that requires students to follow orders, imitate or memorize. However, to implement this center learning model it is not easy to fulfill the requirements in its implementation as stated by the Ministry of National Education (2006) that in the steps of implementing the learning center process includes: (1) preparation; (2) process learning; and (3) evaluation. However, in practice there are still many centers for implementing learning models that are not in accordance with the provisions that should be.

The results of preliminary observations in the field on January 20, 2017 in some kindergartens who have applied the learning center model in Sungai Gelam District show that there are some institutions that have not implemented the opening play (experience of rough movements) for 15 minutes before entering the room, as well as during the circle not seen in the learning process while one of the special features of the central learning 
model itself is the current circle. In accordance with the results of preliminary observations made by researchers, the researcher is interested in conducting research in the Sungai Gelam Subdistrict, because according to researchers in the Gelam Subdistrict is an area of very high economic progress, this is evidenced by the majority of the population who own plantation land palm oil but for education it still needs to get more attention especially at the level of early childhood education.

The results of an initial survey conducted by researchers on January 27, 2017 in the office of the education service unit (KUPP) Sungai Gelam District succeeded in getting data that in Sungai Gelam District there were 38 PAUD institutions with a classification of 30 TK institutions and $8 \mathrm{~KB}$ institutions.

From 30 TK institutions in Sungai Gelam Subdistrict, data was obtained that there were 6 institutions that had implemented the learning center model. Another reason why researchers want to do this research is because the problems that are happening right now at the institution need to be proven by the existence of data and real evidence in the field, so that in the future it can be given the right action.

\section{METHOD}

This research is a descriptive study, according to Sukmadinata (2013). Descriptive research is research that attempts to describe the state of the subject at the time (Sutja, 2012), or describe the field as it is. The population and sample research show in the Table 1.

Table 1

Population and Research Samples.

\begin{tabular}{|c|l|c|}
\hline No & \multicolumn{1}{|c|}{ Institution Name } & Total \\
\hline 1 & TK Miftahul Ulum Petaling Jaya & 5 Teacher \\
\hline 2 & TK Al- Ikhlas Blok B & 4 Teacher \\
\hline 3 & TK Handayani 3 & 5 Teacher \\
\hline 4 & TK Karunia & 3 Teacher \\
\hline 5 & TK Perintis & 4 Teacher \\
\hline 6 & TK Darul Hijrah & 6 Teacher \\
\hline \multicolumn{2}{|c|}{ Total } & 27 Teacher \\
\hline
\end{tabular}

There are two data in this research, namely quantitative data and qualitative data. And the data sources in this study are secondary data sources and primary data sources. In this study three data collection techniques were used namely through questionnaires, observation and interviews.

In this study using two data analysis techniques in the form of statistical data analysis techniques to analyze the data obtained from the distribution of questionnaires and the results of observation and analysis of nonstatistical data to analyze the data from interviews.

\section{A. Questionnaire}

\section{RESULTS}

The results of the questionnaire identifying the implementation of the learning center model in Kindergarten Sungai Gelam District of Muaro Jambi for each indicator can be seen in the following Table 2 .

\section{B. Observation}

The results of observations identifying the implementation of the center learning model in TK
Sungai Sungai Gelam District of Muaro Jambi for each indicator can be seen in the following Table 3 .

Table 2

Results of the Questionnaire Identify the Implementation of the Learning Center Model

\begin{tabular}{|c|l|c|c|c|}
\hline \multirow{2}{*}{ No } & \multirow{2}{*}{ Indicator } & \multicolumn{2}{|c|}{ Response } & Quality aspects \\
\cline { 3 - 5 } & & Yes & No & \\
\hline 1 & Preparation & 76 & 24 & Good \\
\hline 2 & Learning process & 80 & 20 & Good \\
\hline 3 & Evaluation & 76 & 24 & Good \\
\hline & Average & $\mathbf{7 8}$ & $\mathbf{2 2}$ & Good \\
\hline
\end{tabular}

Table 3

Observation Results of the Identification of the Implementation of the Learning Center Model

\begin{tabular}{|c|l|c|c|c|}
\hline \multirow{2}{*}{ No } & \multirow{2}{*}{ Indicator } & \multicolumn{2}{|c|}{$\begin{array}{c}\text { Observation } \\
\text { Results }\end{array}$} & \multirow{2}{*}{ Quality aspects } \\
\cline { 3 - 4 } & & T & TT & \\
\hline 1 & Preparation & 76 & 24 & Good \\
\hline 2 & Learning process & 76 & 24 & Good \\
\hline 3 & Evaluation & 74 & 26 & Good \\
\hline \multicolumn{2}{r}{ Average } & $\mathbf{7 6}$ & $\mathbf{2 4}$ & Good \\
\hline
\end{tabular}

\section{Interview}

The results of interviews with six different sources showed that the teachers had implemented the central learning model. This can be seen from the results of respondents' answers to the questions raised. For example, the teacher can describe in detail the steps in the center of the learning process correctly. El-Khuluqo (2015) also argues that management in education is also very necessary, because if something cannot be managed or managed properly then whatever has been achieved will not mean pap-anything and the goals will not be achieved.

\section{A. Identification}

\section{DISCUSSION}

Identification comes from the word Identify which means to examine, or examine. Identification is an activity that seeks, finds, collects, researches, registers, records data and information from needs in the field. According to the third edition of the Poerwadarminta (2014) explains the meaning of identification is a determination or determination of identity (people, things, etc.). If you look at the opinions above identification is interpreted as a process to determine and determine something you want to know.

According to the Big Indonesian Dictionary (KBBI) the fourth edition of the Language Center states that the meaning of identification is identification, proof of self, determining or establishing identity (people or objects, etc.) (Poerwadarminta, 2014). Referring to the two opinions above about the meaning of the word identification is not much different both are interpreting the word identification as a process of determining and also determine something that you want to know.

\section{B. Center Learning Model}

Asmawati (2014) again argues that center learning is learning that combines various aspects of development, discussed extensively and deeply that prioritizes daily life, which integrates sub themes into all areas of plural intelligence development. From the overall opinion of the 
experts above about the center learning model it can be concluded that the center learning model is one of the excellent learning models to be applied to early childhood today by considering all the principles and also the objectives of the implementation of the center learning model itself and the compatibility of the characteristics of students.

\section{Basic Principles of Learning Center}

The principle used is the principle of individualization of learning experiences. Each child is allowed to choose a learning center that will be used for exploration and play. The media and play environment used in each center must be safe, comfortable and cause interest for children and there needs to be enough time to explore, so that children feel comfortable in learning.

The principles of central learning as a whole refer to the needs of students to develop more optimally. Child-centered learning activities are built on the basis that each child has different modalities, learning styles and interests in the knowledge he wants to know. This is in line with the opinion of Day in Sujiono \& Sujiono (2010) which states that the center of learning activities can adapt to differences in learning styles, the level of maturity and development of children, and differences from different backgrounds.

\section{Objectives of the Learning Center}

Similarly, the opinion of Sujiono \& Sujiono (2013) who said the exact same thing about the center of the learning model objectives namely:

1. This model is intended to stimulate all aspects (plural intelligences) through directed play.

2. This model creates learning settings that stimulate children to be active, creative, and continue to think by exploring their own experiences (not just following orders, imitating or memorizing).

3. Equipped with standard operational standards, which are centered on activity centers and when children are in a circle with educators so that they are easy to follow.

Center learning model is very concerned about the support of learning satisfaction, games and emotional atmosphere of children. This must be shown starting from the pick-up of the child when entering the school environment, the teacher must position himself as a representative of parents, the child is given a choice of various centers as a place of learning and a variety of support to facilitate the achievement of development.

\section{E. Characteristics of the Learning Center}

The center learning model places great importance on the child's feelings of satisfaction when learning, playing, exploring, and channeling his interests. According to Sujiono \& Sujiono (2013) the characteristics of the center learning model include:

1. Child-centered learning.

2. Placing the playing environment settings as an important starting point.

3. Give full support to every child to be active, creative, and dare to make their own decisions.
4. The role of educators as facilitators, motivators and evaluators.

5. Children's activities are centered at play centers that function as centers of interest.

6. Have a standard operational procedure (SPO) that is standard (both at the center and during the circle).

7. Provision of footing before and after children play in a circular sitting position (in a circle).

\section{F. Steps in Implementing the Center Learning Model}

Department of National Education (2006) that the steps in implementing BCCT learning or centers include 3 stages, namely:

1. Preparation

2. Learning Process

a. Main environmental management

b. Welcoming children

c. Main opening

d. Transition

e. The core activities in each group

f. Eat lunch together

g. Closing activities

3. Evaluate or assessment

Consistent with the above 3 experts' opinions and shared the steps or procedures for implementing a centralized learning model, Mayeski only publishes and clarifies the opinion of the Directorate of Early Childhood and is covered by the Kemendiknas which concludes covering preparation, stage learning process and final stage of evaluation or assessment.

\section{CONCLUSION}

Based on the results of research data processing as stated above, then in this section, the author can express some conclusions from this research as follows:

1. Identification of the implementation of the learning center model in Kindergarten of Sungai Gelam Subdistrict, Muaro Jambi Regency as a whole (General) is in the category of "Good" with the results of the questionnaire percentage reaching $78 \%$ and the percentage of observations reaching $76 \%$ as well as being strengthened with the overall interview results also stated well in its implementation.

2. Identification of the implementation of the learning center model in Kindergarten of Sungai Gelam Subdistrict, Muaro Jambi District based on the preparation indicator is at "Good" quality with the results of the questionnaire percentage reaching $76 \%$ and the observation percentage results reaching $76 \%$ and the interview results also stated well on the preparation indicators.

3. Identification of the implementation of the learning center model in Kindergarten of Sungai Gelam District, Muaro Jambi District, in the learning process indicator is in "Good" quality with the results of the questionnaire percentage of $80 \%$ and the percentage of observations reaching $76 \%$ and strengthened from the results of interviews that stated well in the learning process indicators.

4. Identification of the implementation of the learning center model in Kindergarten of Sungai Gelam Subdistrict, Muaro Jambi District, the evaluation 
indicators are of "Good" quality with the results of the questionnaire percentage reaching $76 \%$ and the observation percentage results reaching $74 \%$ and strengthened from the results of the interviews which stated both in the evaluation indicators.

\section{REFERENCES}

[1] Asmawati, L. 2014. Perencanaan Pembelajaran PAUD. Bandung: Remaja Rosdakarya.

[2] Department of National Education. 2006. Pedoman Penerapan Pendekatan Beyond Centers and Circle Time (BCCT) (Pendekatan Sentra dan Lingkaran) dalam Pendidikan Anak Usia Dini. Jakarta: Kemendiknas.
[3] El-Khuluqo, I. 2015. Manajemen PAUD (Pendidikan Anak Usia Dini) Pendidikan Taman Kehidupan Anak. Yogyakarta: Pustaka Pelajar.

[4] Ministry of National Education. 2006. Pedoman Pengembangan Silabus di Taman Kanak-Kanak. Jakarta: Kemendiknas.

[5] Poerwadarminta, W. J. S. 2014. Kamus Umum Bahasa Indonesia. Jakarta: PT Balai Pustaka.

[6] Susanto, A. 2014. Perkembangan Anak Usia Dini Pengantar dalam Berbagai Aspeknya. Jakarta: Kencana Prenanda Media Group.

[7] Sutja. 2012. Panduan Penulisan Skripsi. Jambi: Program Studi Bimbingan Konseling FKIP Universitas Jambi. 